\title{
The Effect of the Psychological Capital and Personality Characteristics of Employees on Their Organizational Commitment and Contribution to the Work: A Qualitative Research on Managers
}

\author{
Ebru Yildiz ${ }^{1}$ \\ ${ }^{1}$ Faculty of Economics and Administrative Sciences, Department of Business, Beykent University, Istanbul, Turkey \\ Correspondence: Assist. Prof. Dr. Ebru Yildiz, Faculty of Economics and Administrative Sciences, Department of \\ Business, Beykent University, Ayazaga-Maslak Campus, Sarıyer-Istanbul, Turkey. Tel: 90-444-1997.
}

Received: July 24, 2017

Accepted: August 11, 2017

Online Published: August 15, 2017

doi:10.5430/jms.v8n4p34

URL: https://doi.org/10.5430/jms.v8n4p34

\begin{abstract}
This study reveals the views and thoughts of managers regarding the employees' psychological capital, personality characteristics and organizational commitment and their contribution to the work. A qualitative research was conducted in order to reveal the views and thoughts of the managers of a furniture accessories manufacturing company regarding the concepts in question using the in-depth interview method. The data obtained from the interviews were evaluated and interpreted by being subjected to the content analysis.

According to the findings of the research, managers believe that both the psychological capital and personality characteristics of employees contribute significantly to the work and the enterprise, and these characteristics also have effects on the organizational commitment of employees.
\end{abstract}

Keywords: psychological capital, personality, five-factor personality model, organizational commitment

\section{Introduction}

In an environment of globalization and increasing competition, the survival of enterprises depends on their efficient and effective use of their sources. Human resources are at the top of these sources. The ability to maintain the contribution of employees to the work and the enterprise consistently, working with team spirit within the organization, feeling valuable within the enterprise with an understanding of participatory management and being praised have become important areas of study for the management of enterprises.

In this context, psychological capital attracts attention as a recently examined concept of the organizational behavior field. While developing and strengthening the positive aspects of employees is a significant field of responsibility for enterprises, these studies increase the levels of the organizational commitment of employees.

Similarly, another important subject that should be taken into consideration in terms of organizational behavior is the personality characteristics of employees. It is believed that different personality characteristics have different effects on the organization's achieving its aims.

In this framework, the study is quite significant in that it offers information that will contribute to the literature and practice by making determinations in the light of manager assessments on the contributions/effects of the psychological capital and personality characteristics both on the work and enterprise and organizational commitment.

\section{Theoretical Framework}

\subsection{Psychological Capital}

Psychological capital is based on the positive psychology movement that emerged with an effort to remind the forgotten mission of "determining and building the strengths of people" of the science of psychology. Pioneered by Martin Seligman (1998), this movement was later expanded to organizational environments under the name positive organizational behavior by Fred Luthans. At first; self-efficacy, hope, optimism, subjective well-being, resilience and emotional intelligence were determined and supported for the theoretical construct of the positive organizational behaviour field as structures that are open for development, change and management for performance improvement, that meet the criteria of positive organizational behaviour, and based on unique and valid measurements as well as 
theory and research for the field of organizational behaviour in addition to being positive. Later, the theoretical construct, research, and practices of the field of positive organizational behavior focused mostly on self-efficacy, hope, optimism, and resilience. In subsequent works, Luthans et al. combined these four structures in a superstructure named as psychological capital (Luthans et al., 2005: 252-253).

Luthans, Youssef and Avolio (2007: 3) state that psychological capital is developing in the positive psychological state of the individual and can be characterized as follows:

1. Having the confidence (self-efficacy) that ensures the successful fulfillment of difficult duties by means of showing the necessary effort,

2. Making positive attribution (optimism) on the existing and future success,

3. Re-directing the roads to persevere and achieve the targets to be successful when necessary (hope),

4. Gathering oneself up and maintaining this in the face of problems and difficulties (resilience).

The researches conducted in the field of psychological capital show that the knowledge of the employees on their psychological capital contribute significantly to organizations. Their knowledge on psychological capital shed light for the organizations on sustainability, performance towards the future, the selection of qualified employees and keeping them. The researches conducted show that psychological capital is positively correlated with organizational commitment, job satisfaction, organizational citizenship behavior; and negatively correlated with the intention to leave, counterproductive work behaviors and organizational cynicism. Therefore, it is necessary for organizations to attribute particular importance to the subjects of developing the employees' psychological capital and its effective management.

\subsection{Personality}

A human being is the most complex creature in the universe with aspects such as body, emotion, thought and behaviors. In the effort of understanding people, this complexity makes it hard to define, explain and understand certain concepts. This challenge reveals itself fully in the concept of personality. While personality is a concept that is understood by many people when expressed, difficulties emerge in defining the concept. Therefore, there is not a single definition of personality that the researchers agree on.

Personality originates from the Latin word "Persona", and it means mask. In classical Roman theatre, the mask was a tool used to symbolize the character represented, and not to hide the identity of a character. Personality is the way of thinking, emotions, and behaviors that are constantly exhibited by individuals and affect the expectations, self-perception, values, and attitudes of the individual strongly in time. Personality is the determinant of the reactions of individuals in their relations with other individuals and in the face of various life events. In short, personality is not only about who we are, but also how we are (Ahmadi et al., 2012: 321).

Hogan (2009: 23-24) states that personality, which is a frequently used concept in daily language has two meaning as "the you that you know" and "the you that we know", and these two meanings are used for many different objectives; and it is necessary to differentiate between them for a correct use. "The you that you know" is an individual's own personality from through his/her own eyes. This is how an individual sees himself/herself; his/her hopes, dreams, wishes, values and fears. This is their opinions on getting on well with other people, becoming successful, and adding meaning to life. Whereas "the you that we know" is the personality from the outside. It is how people see an individual starting from his/her behaviors.

In the definitions made by Triandis and Suh (2002: 136), Mayer (2007: 1), Ahmadi et al. (2012: 321), Robbins and Judge (2013: 135), they state that personality covers the features that make up the emotion, thought and behaviour patterns of an individual and the psychological mechanisms behind these patterns; and it is the group of relatively consistent features affecting the understanding, motivation, habits of an individual and the relations with other individuals, that is unique to the individual and differentiates an individual from other people.

And the most frequently used definition of personality was made by Gordon Allport. Allport (1937: 48) defined personality as "the dynamic organization within the individual of those psychophysical systems that determine his unique adjustments to his environment" (Robbins and Judge, 2013: 135).

Certain theoreticians assert that personality may only be investigated by observing external social behaviors. However, most psychologists state that personality is formed within an individual, it may exist in the absence of other individuals and have invisible aspects. Also, certain aspects of personality such as thoughts, memories, and dreams cannot be observed while actions that are clearly seen can be observed. Personality covers the hidden and subconscious aspects, as well as conscious aspects and those that the individual is aware of (Ewen, 2003: 4). 
It is seen that Five-Factor Personality Model is widely used in the literature in expressing personality characteristics, and this model was used in our study. The model in question defines personality differences by regulating personality features in five dimensions, and it is based on the distinctive feature approach. The model explains these five dimensions as extraversion, conscientiousness, agreeableness, neuroticism, and openness to experience. The researches on this model have shown the consistency of the five-factor structure.

Among the factors that make up the Five-Factor Personality Model, extroversion means being talkative, sociable, gregarious, warm-blooded and active. It is assumed that individuals who have high scores in conscientiousness dimension are careful, reliable, organized, hardworking and achievement-oriented. Agreeableness, which is among other features is used as an equivalent of the features of kind, compassionate, benevolent, helpful and self-sacrificing. And individuals who have high scores in neuroticism dimension are qualified as depressed, angry, worried, insecure and pessimistic. The feature of openness to experience means high imagination and creativity.

Personality is one of the most significant values that an individual possesses. This value is very important both individually and in organizational terms. That individuals make a more in-depth interrogation and assessment about their own personality and know their personality characteristics will ensure that they guide their relations, behaviors, preferences, and decisions in a healthier manner in various environments and situations.

Schultz and Schultz (2009: 3) state that personality helps to shape one's experiences and define their limits on success and happiness, and they assert that the expectations of an individual about the future, whether he/she can be a good spouse or parents, and even his/her health may be defined by their personality and the personalities of the people they interact with.

Understanding the personality of individuals is also very important for organizations. For, this information may give the managers important clues on employing individuals in the correct positions, how they can act and how they can feel in various situations (Kappagoda, 2013: 2). However, it is seen that the practices on understanding the personality characteristics of the employees working at the enterprises in our country are quite insufficient. Yildiz (2013: 103-113) reveals results that support this insufficiency in her study.

Studies conducted reveal that personality is correlated with many organizational results such as organizational commitment, job satisfaction, organizational citizenship behavior, organizational trust, leadership, job performance, motivation, burnout, coping with stress, and counterproductive work behaviors. In this context, it is necessary for organizations to make an effort to understand the personality characteristics of their employees and the individuals to be employed in the organization, implement the studies conducted in this direction, and assess the reflection of implementation results to their ways of business behaviour and the whole organization by monitoring the results.

\subsection{Organizational Commitment}

Organizational commitment is defined by Mowday, Steers, and Porter (1979: 226) as "the identification of an individual with a particular organization and the relative power of participating in the organization", and it is characterized by three factors: a strong belief in the acceptance of the aims and values of the organization, being willing to make an effort for the organization and maintaining the membership to the organization. When commitment is defined in this way, it goes beyond a passive commitment to the organization, and an active relation where individuals want to sacrifice from themselves in order to contribute to the welfare of the organization. Therefore, commitment can be understood not only from the beliefs and thoughts of an individual but also his/her actions (Mowday, Steers and Porter, 1979: 226).

Meyer and Allen (1991: 63-64) state that while commitment has many and various definitions, these definitions have at least three elements as an affective commitment to the organization, the perceived cost of quitting the organization and the obligation to stay in the organization. These three elements exist in the commitment model they developed by the researchers in the form of affective commitment, continuance commitment, and normative commitment. Affective commitment means to commit to the organization emotionally and become identified with the organization. Continuance commitment is about the perceived cost of quitting the organization; while normative commitment is about the perceived obligation of staying in the organization.

Researches show that organizational commitment plays an important part in understanding the working behaviors of the employees (Mowday, Steers and Porter, 1979: 225; Mowday, Porter and Steers, 1982: 19; Kumar and Bakhshi, 2010: 25). Studies conducted show the relationship between organizational commitment and job satisfaction, organizational citizenship behaviour, job performance, employee motivation, turnover, intention to leave, absenteeism and counterproductive work behaviors (Mathieu and Zajac, 1990: 171; Meyer and Allen, 2004: 2; Kumar and Bakhshi, 2010: 25; Kappagoda, 2013: 1). Also, Kappagoda (2013: 1-2) states that low level of 
commitment to the organization is related to low level of morale, negatively affects the behaviours of altruism and compliance, and may prevent the skill of the organization to employ qualified employees with the development of a negative outlook on the organization by the individuals outside the organization due to the employees who are not committed to the organization.

Mathieu and Zajac (1990: 171) gaining a wider perspective on organizational commitment has effects on the employees, organizations and the society as a whole; and the society may benefit from the organizational commitment of the employees in terms of a low turnover, higher national productivity, and work quality.

\section{The Qualitative Research Applied to Business Managers and Its Findings}

\subsection{Methodology}

The aim of the research is to reveal the opinions of the managers regarding the employees' psychological capital and five-factor personality dimensions to their organizational commitment and contribution to the work, the problems that the managers face or may encounter in this respect and suggestions of solution.

All managers consisting of the general manager, production, accounting and finance, human resources and marketing managers, of a furniture accessories manufacturer established in Hatay that is active both at national and international level with a total of 217 blue and white collar employees were interviewed. In the study that uses the in-depth interview method, the managers were directed the open-ended questions on the variables in question. The interviews held with each manager were recorded, and then the notes taken were combined and subjected to content analysis.

The study was conducted in only one enterprise. Although this is a limitation, it's thought that studying a single enterprise would achieve homogenity in determining, evaluating and interpretation of the opinions of managers in the framework of they have been lived in their enterprise.

\subsection{Findings}

The responses received in the interview held with five managers, being the general manager, production, accounting and finance, human resources and marketing manager, are shown in the tables below with their explanations.

Table 1. The themes that come to the forefront in manager opinions regarding the contribution of the psychological capitals of the employees to the work and the enterprise and their frequencies

\begin{tabular}{llrr}
\hline $\begin{array}{l}\text { Components of the } \\
\text { Psychological Capital }\end{array}$ & Featured Themes & n & \% \\
\hline \multirow{5}{*}{ Self-Efficacy } & Contribution to the individual and organizational performance & 3 & 23,0 \\
\cline { 2 - 4 } & Planned working & 2 & 15,4 \\
\cline { 2 - 4 } & Sharing the authority & 1 & 7,7 \\
\cline { 2 - 4 } & Decisiveness in the thought and work & 1 & 7,7 \\
\cline { 2 - 4 } & Using the time well & 1 & 7,7 \\
\cline { 2 - 4 } & Being an example to one's colleagues & 1 & 7,7 \\
\cline { 2 - 4 } & Being willing to work & 1 & 7,7 \\
\cline { 2 - 4 } & Being eager to act as a leader & $\mathbf{1 3}$ & $\mathbf{1 0 0 , 0}$ \\
\cline { 2 - 4 } & Perfectionism & 4 & 26,7 \\
\cline { 2 - 4 } & Having positive motivation & 4 & 26,7 \\
\cline { 2 - 4 } & Total & 2 & 13,3 \\
\hline & The ability to develop various business methods & 13,3 \\
\cline { 2 - 4 } & Problem solving & 2 \\
\cline { 2 - 4 } & Solving a problem quickly and easily & 1 \\
\cline { 2 - 4 } & Developing ideas & & 7,7 \\
\cline { 2 - 4 } & Focusing on achieving the organization goal & 1 \\
\hline
\end{tabular}




\begin{tabular}{llrr}
\hline & Using the time well & 1 & 6,7 \\
\cline { 2 - 4 } Total & $\mathbf{1 5}$ & $\mathbf{1 0 0 , 0}$ \\
\hline Being positive and expanding this to the whole organization & 4 & 33,4 \\
\hline Increasing work efficiency & 2 & 16,7 \\
\hline Contrimism & Increasing the motivation & 2 & 16,7 \\
\hline & Developing good relations with the customer & 1 & 8,3 \\
\hline Ensuring solidarity between colleagues & 1 & 8,3 \\
\hline Being happy & 1 & 8,3 \\
\hline Total & 1 & 8,3 \\
\hline Being calm and controlled & $\mathbf{1 2}$ & $\mathbf{1 0 0 , 0}$ \\
\hline Preventing the mistake & 6 & 30,0 \\
\hline Contribution to individual and organizational performance & 6 & 30,0 \\
\hline Being careful & 3 & 15,0 \\
\hline & Focusing on the work & 2 & 10,0 \\
\hline Gaining respect in the eyes of the customer & 2 & 10,0 \\
\hline Total & $\mathbf{2 0}$ & $\mathbf{1 0 0 , 0}$ \\
\hline
\end{tabular}

The managers were asked the contribution of employees' psychological capitals to the work and enterprise as a separate question for each component, and the answers are shown in Table 1.

$23 \%$ of 13 answers received about self-efficacy is that it contributes to performance, while $15,4 \%$ is that it ensures planned working. Other answers include eight contributions that are different from one another.

It is seen that the ability to develop various business methods and the contributions of problems solving come to the forefront in the answers regarding hope. It stands out that other answers are based on problem solving and idea development.

In the component of optimism, being positive and expanding this to the whole organization, increasing work efficiency and the contribution to organizational performance make up approximately $67 \%$ of the answers. In the interview, the managers were also asked whether optimism has a negative effect, and it was seen that the answers received focus on the risk of excessive optimism. According to the managers, optimism may not allow for monitoring and controlling the work, and prevent seeing the real situation. The managers stated that the mistakes and errors of excessively optimistic employees might sometimes be disregarded, and it is necessary not to be very optimistic, and it will be beneficial to be a bit skeptical especially in works that require meticulousness.

Being calm and controlled and preventing the mistake comes at the top of the contributions of resilience to the work and enterprise at the same rate, and make up $60 \%$ of the answers. It is seen that another contribution of resilience is the contribution to the individual and organizational performance at a rate of $15 \%$, and, being careful and focusing on the work are two important contributions. 
Table 2. The themes that come to the forefront in manager opinions regarding the effects of the psychological capitals of the employees to their organizational commitment and their frequencies

\begin{tabular}{|c|c|c|c|}
\hline $\begin{array}{l}\text { Components of the } \\
\text { Psychological Capital }\end{array}$ & Featured Themes & $\mathbf{n}$ & $\%$ \\
\hline \multirow{4}{*}{ Self-Efficacy } & $\begin{array}{l}\text { That the skills of the employees are valued by the top } \\
\text { management }\end{array}$ & 4 & 66,6 \\
\hline & Being praised by one's colleagues & 1 & 16,7 \\
\hline & $\begin{array}{l}\text { That the employees are aware of their abilities and } \\
\text { use them in achieving the enterprise purposes }\end{array}$ & 1 & 16,7 \\
\hline & Total & 6 & 100,0 \\
\hline \multirow{4}{*}{ Hope } & $\begin{array}{l}\text { The positive feeling that the effort to offer and } \\
\text { implement different ways create in the employee }\end{array}$ & 2 & 50,0 \\
\hline & $\begin{array}{l}\text { Having positive emotions and thoughts about the } \\
\text { enterprise }\end{array}$ & 1 & 25,0 \\
\hline & $\begin{array}{l}\text { That the effort of the employee to find different } \\
\text { alternatives is praised by the enterprise }\end{array}$ & 1 & 25,0 \\
\hline & Total & 4 & 100,0 \\
\hline \multirow{4}{*}{ Optimism } & $\begin{array}{l}\text { Having positive emotions and thoughts about the } \\
\text { enterprise }\end{array}$ & 2 & 40,0 \\
\hline & Making sacrifice & 2 & 40,0 \\
\hline & Adopting enterprise objectives more easily & 1 & 20,0 \\
\hline & Total & 5 & 100,0 \\
\hline \multirow[t]{2}{*}{ Resilience } & $\begin{array}{l}\text { Developing positive emotions and thoughts for the } \\
\text { enterprise }\end{array}$ & 1 & 100,0 \\
\hline & Total & 1 & 100,0 \\
\hline
\end{tabular}

The effect of the employees' psychological capital to their organizational commitment was asked to the managers separately for each component, and the answers are shown in Table 2.

The managers stated that the appreciation of the skills of the employees by the top management and their colleagues has the biggest effect regarding the effect of self-efficacy on organizational commitment. In other words, the more valued the skills of the employees are, the higher the employee is committed to the enterprise.

According to managers, hopeful employees have positive emotions and thoughts about themselves and the enterprise with the contribution they create by developing different alternatives on the solution to a great extent. This positive emotion and thought affect the commitment of the employee to the organization positively. Also, the managers state that the efforts of hopeful employees to find different alternatives will be valued by the enterprise.

Having positive emotions and thoughts about the enterprise and making sacrifices come to the forefront as two important elements that create the effect of optimism on organizational commitment. Also, easier adoption of the enterprise objectives by the employee is another factor that affects organizational commitment.

In the effect of resilience on organizational commitment, only one manager said that the development of positive emotions and thoughts by the employee towards the enterprise would affect commitment positively. 
Table 3. Themes that come to the forefront in manager opinions for the strengthening of psychological capital and their frequencies

\begin{tabular}{lrr}
\hline Featured Themes & n & \% \\
\hline Providing personal development and on-the-job training & 5 & 27,8 \\
\hline $\begin{array}{l}\text { Taking into consideration the suggestions of the employees } \\
\text { and giving feedback }\end{array}$ & 422,1 \\
\hline Being constructive in criticisms & 2 & 11,1 \\
\hline Placing the right employee to the right position & 2 & 11,1 \\
\hline Ensuring motivation & 2 & 11,1 \\
\hline Establishing sincere intimacy with the employees & 1 & 5,6 \\
\hline Creating team spirit & 1 & 5,6 \\
\hline Improving the physical working conditions & 1 & 5,6 \\
\hline Total & $\mathbf{1 8}$ & $\mathbf{1 0 0 , 0}$ \\
\hline
\end{tabular}

The answers at the top in manager opinions taken for strengthening the psychological capital of the employees shown in Table 3 are personal development and on-the-job training, taking into consideration the suggestions of the employees and providing them feedback. Also; being constructive in criticisms, motivating the employees and the selection of suitable employees for the job are other remarkable suggestions.

Table 4. Themes that come to the forefront in manager opinions on the contributions/effects of five-factor personality dimensions of the employees to the work and the enterprise and their frequencies

\section{Five-Factor}

Personality

Featured Themes

n $\%$

Dimensions

\begin{tabular}{|c|c|c|c|}
\hline \multirow{9}{*}{ Extraversion } & Effective communication with the customer and persuasion & 6 & 26,1 \\
\hline & Achieving the targets & 6 & 26,1 \\
\hline & Spreading positive energy to the environment & 3 & 13,1 \\
\hline & Being an example for one's colleagues and motivating them & 3 & 13,1 \\
\hline & Gaining the love and appreciation of the customer & 2 & 8,7 \\
\hline & Providing ease to the managers & 1 & 4,3 \\
\hline & Working excitedly & 1 & 4,3 \\
\hline & Positive effect on corporate image & 1 & 4,3 \\
\hline & Total & 23 & 100,0 \\
\hline \multirow{8}{*}{ Conscientiousness } & Ensuring that the work is performed correctly and on time & 8 & 38,1 \\
\hline & Decrease in errors & 2 & 9,5 \\
\hline & $\begin{array}{l}\text { Making it easier to achieve the targets of the department and } \\
\text { enterprise }\end{array}$ & 2 & 9,5 \\
\hline & Increasing productivity & 2 & 9,5 \\
\hline & Increasing job performance & 2 & 9,5 \\
\hline & Being an example to other employees & 2 & 9,5 \\
\hline & Delegation of authority & 1 & 4,8 \\
\hline & That the enterprise trusts the employee & 1 & 4,8 \\
\hline
\end{tabular}




\begin{tabular}{|c|c|c|c|}
\hline & Gaining the trust of the customer & 1 & 4,8 \\
\hline & Total & 21 & 100,0 \\
\hline \multirow{9}{*}{ Agreeableness } & Ensuring that the enterprise achieves its objective & 4 & 20,0 \\
\hline & Helping one's colleagues & 3 & 15,0 \\
\hline & Being an example to other employees & 3 & 15,0 \\
\hline & Playing a conciliating role & 3 & 15,0 \\
\hline & Contribution to being a team & 3 & 15,0 \\
\hline & Obeying the rules & 2 & 10,0 \\
\hline & Contribution to job performance & 1 & 5,0 \\
\hline & Overcoming problems more easily & 1 & 5,0 \\
\hline & Total & 20 & 100,0 \\
\hline \multirow{8}{*}{ Neuroticism } & Conflicts with colleagues & 5 & 21,7 \\
\hline & Difficulty in controlling oneself & 5 & 21,7 \\
\hline & Instability in performance & 4 & 17,4 \\
\hline & Instability in work & 3 & 13,1 \\
\hline & A negative outlook on the work and the enterprise & 2 & 8,7 \\
\hline & The failure to cope with stress & 2 & 8,7 \\
\hline & Feeling insecure & 2 & 8,7 \\
\hline & Total & 23 & 100,0 \\
\hline \multirow{4}{*}{$\begin{array}{l}\text { Openness to } \\
\text { Experience }\end{array}$} & Finding new methods and ideas & 5 & 71,4 \\
\hline & $\begin{array}{l}\text { That the employee motivates the manager and colleagues with } \\
\text { innovative ideas }\end{array}$ & 1 & 14,3 \\
\hline & $\begin{array}{l}\text { The positive reflection of the solutions offered by the employees } \\
\text { on the customer }\end{array}$ & 1 & 14,3 \\
\hline & Total & 7 & 100,0 \\
\hline
\end{tabular}

Table 4 includes manager opinions on the contributions/effects of five-factor personality dimensions of the employees to the work and the enterprise. More than half of 23 answers received on extraversion were expressed by the managers as the contribution to the work and the enterprise in the form of effective communication with the customer and persuasion, and achieving the targets. Also, that extrovert employees spread positive energy around them, be examples to their colleagues and motivate them are among other remarkable contributions.

In the answers regarding the conscientiousness, ensuring that the work is performed correctly and on time has been expressed as the most important element that contributes to the work and the enterprise. Additionally; the decrease in errors, increasing productivity and job performance, making it easier to achieve the targets and being an example for other employees are among other remarkable contributions.

In the dimension of agreeableness, ensuring that the enterprise achieves its aim has been indicated as the primary contribution. Other important contributions are listed as helping one's colleagues and being an example to them, playing a conciliating role and contributing to being a team.

According to managers, neurotic employees may conflict with their colleagues, have difficulty in controlling themselves and may be instable in their performances. The employees with these features are individuals with a high possibility to change jobs; they may approach negatively to their enterprise and work, fail to cope with stress and feel themselves insecure.

Five of seven answers given about openness to experience show that finding new methods and ideas is the most important contribution to the work and the enterprise. 
The behavior patterns of the managers and what they can be in possible problems that the difference in personality characteristics may lead to in the enterprise were also asked in the interview. As a common opinion, the managers expressed that they interview the employees one-to-one in such situations, try to understand the cause of the problem, make the necessary warning, but in case the problem cannot be solved, they share the problem with the General Manager.

Table 5. Themes that come to the forefront in manager opinions on the effects of five-factor personality dimensions of the employees on their organizational commitment and their frequencies

\begin{tabular}{|c|c|c|c|}
\hline $\begin{array}{l}\text { Five-Factor } \\
\text { Personality } \\
\text { Dimensions }\end{array}$ & Featured Themes & $\mathbf{n}$ & $\%$ \\
\hline \multirow{3}{*}{ Extraversion } & $\begin{array}{l}\text { That the employee reflects his/her positivity on the work and the } \\
\text { enterprise }\end{array}$ & 5 & 83,3 \\
\hline & $\begin{array}{l}\text { The value that an employee praised by the customer will feel in the } \\
\text { enterprise }\end{array}$ & 1 & 16,7 \\
\hline & Total & 6 & 100,0 \\
\hline \multirow{5}{*}{ Conscientiousness } & Caring about and embracing the work and the enterprise & 3 & 33,4 \\
\hline & Not making a mistake and caring about the work performed & 2 & 22,2 \\
\hline & Having the sense of serving best to the aim of the enterprise & 2 & 22,2 \\
\hline & That the enterprise praises the employee & 2 & 22,2 \\
\hline & Total & 9 & 100,0 \\
\hline \multirow{7}{*}{ Agreeableness } & Adopting the aims and values of the enterprise & 4 & 28,6 \\
\hline & Creating cooperation & 3 & 21,4 \\
\hline & Making more sacrifice & 3 & 21,4 \\
\hline & Being positive & 2 & 14,4 \\
\hline & Playing a conciliating role & 1 & 7,1 \\
\hline & Being loved by the managers and colleagues & 1 & 7,1 \\
\hline & Total & 14 & 100,0 \\
\hline \multirow{4}{*}{ Neuroticism } & Disturbing the peace of the working environment & 2 & 40,0 \\
\hline & Not working steadily & 2 & 40,0 \\
\hline & The possibility to quit to work at anytime & 1 & 20,0 \\
\hline & Total & 5 & 100,0 \\
\hline \multirow{4}{*}{$\begin{array}{l}\text { Openness to } \\
\text { Experience }\end{array}$} & The desire to use new ideas for the enterprise & 3 & 42,8 \\
\hline & $\begin{array}{l}\text { That the ideas suggested is valued by the enterprise, and the } \\
\text { positive emotion created by this in the employee }\end{array}$ & 3 & 42,8 \\
\hline & Being open to finding new work alternatives & 1 & 14,4 \\
\hline & Total & 7 & 100,0 \\
\hline
\end{tabular}

Manager opinions on the effects of five-factor personality dimensions of the employees on their organizational commitment are shown in Table 5. In the light of manager opinions, five of six answers given on the effect of extroversion on organizational commitment showed that the positivity of the employee reflects on the work and the enterprise.

Managers stated that caring about and embracing the work and the enterprise is the most important factor in the effect of conscientiousness on organizational commitment. Other factors that affect commitment are not making a 
mistake and caring about the work performed, having the sense of serving best to the aim of the enterprise and that the enterprise praises the employee.

Adopting the aims and values of the enterprise, creating cooperation and sacrificing more are the elements that come to the forefront in the effect of agreeableness on organizational commitment.

The managers primarily stated the effect of neuroticism on organizational commitment as disruption the peace of the working environment and not working steadily. Additionally, they also stated that employees with these features have the risk of quitting the work at any time.

It is seen that the desire to use new ideas within the enterprise and that the ideas suggested are valued by the enterprise and the positive emotion created by this in the employee plays a significant role in the effect of openness to experience on organizational commitment. On the other hand, managers pointed to the fact that employees with these features may look for different work alternatives outside the enterprise, and this may lead to a negative effect on staying in the enterprise.

Managers state that different personality characteristics may affect organizational commitment, these differences may be natural, and therefore, the organizational commitment levels of the employees may also differ. Nevertheless, they also emphasized that what is important is to keep the employees together and ensure that they work in accordance with the aims of the enterprise, despite the difference in these personality characteristics.

Table 6. Themes that come to the forefront in manager opinions on the factors that affect the organizational commitment levels of employees in general and their frequencies

\begin{tabular}{lrr}
\hline Featured Themes & n & \% \\
\hline Wage and social rights & 23 & 27,4 \\
\hline Obligation & 8 & 9,5 \\
\hline Hatay's position & 7 & 8,3 \\
\hline Different work alternatives & 7 & 8,3 \\
\hline Debt of gratitude & 6 & 7,1 \\
\hline Having shown much effort for the enterprise & 5 & 5,9 \\
\hline Long working period & 4 & 4,8 \\
\hline Considering oneself as part of the enterprise & 4 & 4,8 \\
\hline Working willingly & 4 & 4,8 \\
\hline That the work does not fulfill the expectations of the employee & 4 & 4,8 \\
\hline Investing in employees & 3 & 3,6 \\
\hline Making sacrifice & 2 & 2,4 \\
\hline The failure to control the informal information flow & 2 & 2,4 \\
\hline Manager-employee relations without sincerity & 2 & 2,4 \\
\hline An enterprise that is far from the city & 2 & 2,4 \\
\hline The number of employees from the same family & 1 & 1,1 \\
\hline Total & $\mathbf{8 4}$ & $\mathbf{1 0 0 , 0}$ \\
\hline
\end{tabular}

Table 6 shows the factors that affect the general organizational commitment levels of the employees. Managers stated that the most important element that affects the organizational commitment levels of the employees is wage and social rights. In addition to this, while obligation ranks second, managers emphasized the position of Hatay next. It can be said that the political and economic problems encountered in the region for the last few years bring this element to the forefront.

Although it has a small rate among the answers, the number of the employees from the same family attracts the attention as a different element. The problems encountered by the region and limited working opportunities require the co-working of more than one person from the same family in the enterprise. According to the managers, this 
factor has both positive and negative effects, and co-working family members affect each other about developing positive or negative emotions and thoughts about the enterprise. Therefore, the decision to leave or stay in the enterprise is shaped under this effect.

Other factors affecting the commitment are as follows: Different work alternatives, debt of gratitude, having shown much effort for the enterprise, long working period, considering oneself as part of the enterprise, working willingly, that the work does not fulfill the expectations of the employee, investing in employees, making sacrifice, the failure to control the informal information flow, manager-employee relations without sincerity and an enterprise that is far from the city. As is seen, while some of these factors affect the commitment to the organization positively, some may have negative effects.

Table 7. The themes that come to the forefront in manager opinions on the solutions in creating employees' organizational commitment and their frequencies

\begin{tabular}{lcr}
\hline Featured Themes & n & \% \\
\hline Particularity in wage and social rights & 8 & 22,2 \\
\hline Establishing warm relations with the employees & 5 & 13,7 \\
\hline Just treatment & 4 & 11,1 \\
\hline Exchanging ideas with the employees & 3 & 8,3 \\
\hline Establishing a system of suggestion & 3 & 8,3 \\
\hline Communication between the managers & 2 & 5,6 \\
\hline The system of prizing & 2 & 5,6 \\
\hline Occupational health and safety practices & 2 & 5,6 \\
\hline Evaluation of Employee Satisfaction Survey & 2 & 5,6 \\
\hline Social activities & 2 & 5,6 \\
\hline Placing the right worker to the right position & 1 & 2,8 \\
\hline Providing training on occupational subjects & 1 & 2,8 \\
\hline Adhering to working hours & 1 & 2,8 \\
\hline Total & $\mathbf{3 6}$ & $\mathbf{1 0 0 , 0}$ \\
\hline
\end{tabular}

Manager opinions on the solutions for creating organizational commitment in employees are shown in Table 7. The first three suggestions that the managers define in creating organizational commitment are particularity in wage and social rights, establishing warm relations with the employees and just treatment. It is seen that these are followed by the exchange of ideas and the establishment of a system of suggestions. These are followed by the factors with the same frequency: the communication between the managers, the prizing system, occupational health and safety practices, the evaluation of the employee satisfaction survey, and social activities. And the last three suggestions were determined as placing the right employee to the right position, providing training in occupational subjects and adhering to working hours.

\section{Conclusion}

This study that reveals manager opinions on the effects of the psychological capitals and personality characteristics of employees on their organizational commitment, and their contributions/effects on the work and the enterprise show that the managers of the enterprise in question are aware of the relevant subjects, but having a wider perspective on the concepts should be an important field of study.

In the interviews held within the scope of the qualitative research, it is seen that managers believe that the higher the psychological capital of the employees, the higher they contribute to the work and the enterprise. Hence, the managers think that the performance and business efficiency of the employees will increase, they will be able to work in a more planned way, their problem-solving approaches will develop, their positivity will spread to the whole organization, and a positive atmosphere can be created in the organization. 
Similarly, managers think that the increase in the psychological capital levels of the employees will increase their level of organizational commitment. According to the managers, that the employee is praised by his/her colleagues and managers for this characteristic and felt valuable with his/her contribution to the enterprise by means of this characteristic will increase the commitment by ensuring his/her have positive emotions and thoughts about the enterprise.

According to the managers who believe that the psychological capital of the employees should be strengthened both for their contribution to the work and the enterprise, and their organizational commitment, providing the employees personal development and on-the-job training, taking into consideration their suggestions and giving them feedback, ensuring their motivation, being constructive in the criticisms and choosing the right person for the job are other main issues that need to be emphasized.

In the light of the evaluations of the managers, it is seen that the personality characteristics of the employees will have contributions/effects on the work and the enterprise. For example, extrovert employees spread positive energy around them, become an example for their colleagues and motivate them. Also, extrovert white collar employees can actively communicate with the customers, and they are more successful in convincing them. Furthermore, employees with high conscientiousness ensure that the work is done correctly and on time, they make fewer mistakes; increase their productivity and personal performance; and make it easier to achieve the targets in the enterprise.

Agreeable employees play a part in the achievement of the enterprise to its aims and conciliating role within the enterprise, contribute to being a team and ensure solidarity in the enterprise. And those employees who are open to experience contribute to the enterprise by finding new methods and ideas for the work and the enterprise.

On the other hand, as the level of neuroticism of the employees increases, they conflict with their colleagues, have difficulty in controlling themselves, exhibit a less stable performance, and act more disharmoniously within the team.

According to the results of the interview, it is seen that managers believe that the positive personality characteristics of the employees also affect their levels of organizational commitment. Employees with positive personality characteristics embrace the work and the enterprise, adopt the aims and values of the enterprise, desire to use new ideas in the enterprise, perform their duties peacefully, and they can reflect their positivity on their work and the enterprise.

In this framework, that managers become informed and receive training in subjects such as communication, conflict management, and stress management and develop their skills in these subjects in order to develop the organizational commitment levels of employees with different personality characteristics are important for business administrations.

In addition to this, that managers, who are aware of the contributions of the personality characteristics at a positive level, are trained on applying the right manner when they encounter people with different characteristics is also utterly important. For, the managers in the enterprise in question generally talk to the employee first when they have a problem in these subjects, make warning when they cannot get any result, and inform the general manager about the subject. However, it will be more accurate the problem as of the first moment they seen it, manage the differences, and guide the characteristic in question to a positive path by communicating with the employee.

Managers first indicate the wage and social rights as factors that affect the organizational commitment levels of the employees. It is also seen that negative economic conditions of the province and that the employees consider their presence in the enterprise as an obligation are also among effective factors. Considering that the enterprise that is the subject of the research consists mainly from blue collar workers, it is found that the effect of the factors in question in their organizational commitment is natural. In this respect, the managers emphasized the importance of being particular about the wage and social rights, just treatment, and establishing warm relations with the employees. Indeed, the literature on organizational commitment also includes many researches that provide the enterprises suggestions on this subject.

Research findings show that training the managers is a field of interest and work that should be taken into consideration in order to increase their awareness regarding these subjects and manage the employees with different characteristics more effectively and efficiently. The planning and implementation of the necessary training by the managers of human resources in these subjects will increase the management quality, as well as ensuring the managers to learn how to motivate their employees with different psychological capital and personality characteristics for the aim of the organization more effectively and efficiently.

The research covers the managers of one enterprise. Therefore, that the findings obtained and the comments only cover the managers of this enterprise is a very important limitation. Studying with samples at sectoral level or cross-sectoral analysis in these subjects will contribute significantly to the scientific field and practice. 


\section{References}

Ahmadi, S. A., Ardi, S. Z., Zare, R., \& Fathizadel, A. R. (2012). Effect of personality characteristic on organizational commitment and job performance. Journal of American Science, 8(1), 321-326.

Ewen, R. B. (2003). An introduction to theories of personality (6th ed.). Lawrence Erlbaum Associates, London.

Hogan, R. (2009). Kişilik ve Kurumların Kaderi. S. Y. Kölay (çev.). İstanbul: Remzi Kitabevi.

Kappagoda, S. (2013). The impact of five-factor model of personality on organizational commitment of English teachers in Sri Lankan Government Schools. 1-10. Retrieved from http://papers.ssrn.com/sol3/papers.cfm?abstract_id=2220719

Kumar, K., \& Bakhshi, A. (2010). The Five-factor Model of Personality and Organizational Commitment: Is There Any Relationship. Humanity and Social Sciences Journal, 5(1), 25-34.

Luthans, F., Avolio, B. J., Walumbwa, F. O., \& Li, W. (2005). The Psychological Capital of Chinese Workers: Exploring the Relationship with Performance. Management and Organization Review, 1(2), $249-271$. https://doi.org/10.1111/j.1740-8784.2005.00011.X

Luthans, F., Youssef, C. M., \& Avolio, B. J. (2007). Psychological Capital: Developing the Human Competitive Edge. USA: Oxford University Press.

Mathieu, J. E., \& Zajac, D. M. (1990). A review and meta-analysis of the antecedents, correlates, and consequences of organizational commitment. Psychological Bulletin, $108(2), \quad$ 171-194. https://doi.org/10.1037/0033-2909.108.2.171

Mayer, J. D. (2007). Asserting the Definition of Personality. The Online Newsletter for Personality Science, (1), 1-4.

Meyer, J. P., \& Allen, N. J. (1991). A three-component conceptualization of organizational commitment. Human Resource Management Review, 1(1), 61-89. https://doi.org/10.1016/1053-4822(91)90011-Z

Meyer, J. P., \& Allen, N. J. (2004). TCM Employee Commitment Survey Academic Users Guide. 1-16. London, Ontario, Canada: The University of Western Ontario, Department of Psychology. Retrieved from http://employeecommitment.com/TCM-Employee-Commitment-Survey-Academic-Package-2004.pdf.

Mowday, R. T., Porter, L. W., \& Steers, R. M. (1982). Employee-organization linkages: The psychology of commitment, absenteeism, and turnover. Academic Press.

Mowday, R. T., Steers, R. M., \& Porter, L. W. (1979). The Measurement of Organizational Commitment. Journal of Vocational Behavior, 14(2), 224-247. https://doi.org/10.1016/0001-8791(79)90072-1

Robbins, S. P., \& Judge, T. A. (2013). Örgütsel Davranış. 14. Basımdan Çeviri. İ. Erdem (çev. ed.). Ankara: Nobel Akademik Yayıncılik.

Schultz, D. P., \& Schultz, S. E. (2009). Theories of Personality (9th ed.). Wadsworth Cengage Learning, USA.

Triandis, H. C., \& Suh, E. M. (2002). Cultural Influences on Personality. Annual Review Psychology, 53, 133-160. https://doi.org/10.1146/annurev.psych.53.100901.135200

Yildiz, E. (2013). İnsan Kaynakları Yönetiminde Davranış Boyutu ve Bir Örnek Olay. Marmara Üniversitesi Sosyal Bilimler Enstitüsü Öneri Dergisi. Cilt 10, Say1 40, 103-113. http://dx.doi.org/10.14783/od.v10i40.1012000353

\section{Note}

Note 1. This study was prepared using the Doctoral thesis presented to Sakarya University Institute of Social Sciences. 